\title{
Editorials
}

\section{Diphthongs, Drug Labels and New Media}

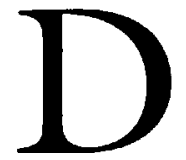

IPHTHONGS have gone. At its 1998

Board meeting the editors of the

Canadian Journal of Anesthesia decided to modify the style of the journal to replace the diphthongs "ae" and "oe" with "e". Commencing January 1999, the CJA has changed to hematology, diarrhea, pediatrics, and encyclopedia but the diphthong will be maintained in proper names, Caesar and Phoebe and in manaevre and subpaena, as is common in Canadian Press spelling. ${ }^{1}$

A diphthong is a "union of two vowels pronounced in one syllable". Latin had two diphthongs ( $\underline{a e}$ and $\underline{\underline{a}}$ ) that were often printed as the ligatures $\underline{a}$ and $\underline{a}$. In English words derived from Latin these are now the diagraphs, $\underline{a \varepsilon}$ and $\underline{\underline{e}}$ which are sometimes modified into $\underline{e}$ representing single vowel sounds. e.g gynącology, orthopądics, an $\underline{a}$ sthesia. In American spelling $\underline{e}$ replaces ae and oe as in gynecology, diarrhea. Evolution has been occurring in English usage to modify the words: mediaeval, oecology. oecumenical. There has even been a gradual change in the English spelling of our specialty, anesthesia. McGill abolished the diphthongs for their department names more than a decade ago and has departments of anesthesia, pediatrics and gynecology. Ironically, the department of anaesthesia at the Royal Victoria Hospital, Montréal, has retained its diphthong. These Latin-derived diphthongs are different from speech sounds in which the articulatory mechanism moves continuously from an initial vowel position to a final vowel position eg. five, save, how.

The change in spelling is not simply a conversion to the American variety of English. We will continue to have colours not colors, fibre not fiber, although both are espoused by the Canadian Press Stylebook ${ }^{2}$ which purports to refer to the authority of the Concise Oxford Dictionary. ${ }^{3}$ It is hoped that the changes will ease communication across the Atlantic, although the time taken to remove the a from $a e$ is probably no less than adding it to $e$. The change in style may not necessarily adopt all the suggestions, such as the use of the split infinitive, that have recently been sanctioned by the New Oxford Dictionary of English. ${ }^{4}$ We have always adopted H.W. Fowler's Modern English Usage which suggested that some split infinitives were defensible, being preferable to real ambiguity and to patent artificiality. ${ }^{5}$ In general, if the style of the text irritates the reader, it should be modified.

Also in January 1999, the CJA will change its drug labelling to International Non-proprietary Names. The European Community suggested that the WHO recommendations, which for the last 40 years have tried to harmonize a recommended international non-proprietary name (rINN) for all medicinal substances, be adopted in January 1998. ${ }^{6}$ The Canadian Journal of Anesthesia has used a somewhat arbitrary approach to drug labelling in the past. Whilst using British approved names for barbiturates, thiopentone, methohexitone etc, and American labels for succinylcholine and lidocaine, it sanctioned both adrenaline and epinephrine. The current changes will confirm the use of thiopental, methohexital, lidocaine, furosemide, epinephrine and succinylcholine.

Finally, this month marks the inauguration of a new section entitled "New Media in Anesthesia", edited by Dr. John Doyle, that will focus on CD-ROMs, videos, software, and especially Internet anesthesia resources. The first issue begins with a CD-ROM review and commentaries discussing an Introduction to the Internet and information on the Anesthesiology Discussion Group at GASNet.

\section{Diphtongues, étiquettes de médicaments et nou-} veaux médias. 
Les diphtongues sont disparues. Lors de la réunion du Conseil d'administration, les rédacteurs du Journal canadien d'anesthésie ont décidé de modifier le style du journal en remplaçant les diphtongues «ae» et «oe» par "e». À partir de janvier 1999, le JCA utilisera hematology, diarrhea, pediatrics, et encyclopedia mais les diphtongues seront maintenues dans les noms propres, Cessar and Phabe et dans manovre et subpana, comme c'est l'usage dans la Presse canadienne.'

Une diphtongue est l'kunion de deux voyelles prononcées en une syllabe». Le latin a deux diphtongues ( $\underline{a \ell}$ et $\underline{o e}$ ) qui sont souvent imprimćes en ligatures $\underline{a}$ et $\underline{a}$. Dans les mots anglais dérivés du latin, les

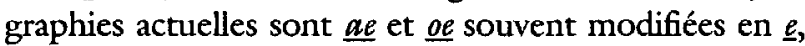
ce qui représente un unique son vocalique : par ex. gynaecology, orthopaedics, anaesthesia. Selon l'orthographe américaine, $\underline{e}$ remplace $\underline{\varepsilon}$ et $\underline{a}$ comme dans gyneccology, diarrhẹ. L'usage anglais a connu une évolution par la modification des mots suivants : mediaeval, oecology, occumenical. Il y a eu un changement graduel de l'orthographe anglaise de notre spécialité, anaesthesia. L'université McGill a aboli les diphtongues du nom de ses départements il y a plus de dix ans : anesthesia, pediatrics and gynecology. Ironiquement, le "department of anaesthesia» au Royal Victoria Hospital de Montréal a conservé la diphtongue. Ces diphtongues dérivées du latin sont différentes des phonèmes pour lesquels les mouvements articulatoires vont continuellement de la position d'une voyelle initiale à celle d'une voyelle finale comme dans "five, save, how".

Le changement d'orthographe n'est pas une simple conversion à une variété américaine de l'anglais. Nous aurons encore colours et non colors, fibre non fiber, bien que les deux formes reçoivent l'adhésion du Canadian Press Stylebook ${ }^{2}$ qui dit s'en remettre à l'autorité du Concise Oxford Dictionary. ${ }^{3}$ C'est à souhaiter que les modifications facilitent la communication de part et d'autre de l'Atlantique, quoique le temps requis pour enlever le a de ae n'est sans doute pas moindre que le temps de l'ajouter à $e$. Le changement de style peut ne pas adopter toutes les suggestions, comme l'usage de l'infinitif éclaté (ou avec césure, lorsque s'intercale un mot entre «to" et le verbe), qui a été récemment approuvé par le New Oxford Dictionary of English. ${ }^{4}$ Nous avons toujours suivi le Modern English Usage de H.W. Fowler qui avance que certains infinitifs éclatés sont justifiables, étant préférables à une réelle ambiguité et à une artificialité manifeste. ${ }^{5}$ En général, quand le style d'un texte irrite le lecteur, il faut le modifier.

En janvier 1999 également, le JCA changera son étiquetage des médicaments pour adopter la Dénomination commune internationale. La Communauté européenne a proposé que les recommandations de l'OMS, qui pendant les quarante dernières années a tenté d'harmoniser une dénomination commune internationale recommandée (DCIr) pour toutes les substances médicinales, soient adoptées en janvier 1998.6 Dans le passé, le Journal canadien d'anesthésie a utilisé un étiquetage des médicaments quelque peu arbitraire. Pendant qu'il utilisait les noms approuvés par les Britanniques pour les «barbiturates, thiopentone, methohexitone», etc. et les étiquettes américaines pour la «succinylcholine» et la «lidocaine», il approuvait les deux termes «adrenaline» et "epinephrine». Les changements actuels vont confirmer l'emploi de "thiopental, methohexital, lidocaine, furosemide, epinephrine et succinylcholine».

Enfin, on inaugure ce mois-ci une nouvelle section intitulée «Nouveaux médias en anesthésie», dirigée par le docteur John Doyle et qui mettra l'accent sur les CD-ROM, les vidéos, les logiciels et surtout sur les ressources Internet en anesthésie. Le premier numéro aborde une revue des CD-ROM et les commentaires sur une Introduction à Internet ainsi que des informations sur les Groupes de discussion en anesthésiologie sur le site GASNet.

\section{References}

1 Caps and Spelling, Toronto: The Canadian Press, 1988.

2 The Canadian Press Stylebook, Bob Taylor (Ed.). Toronto: The Canadian Press, 1989.

3 The Concise Oxford Dictionary, $9^{\text {th }}$ ed. Della Thompson (Ed.). Oxford: Oxford University Press, 1998

4 New Oxford Dictionary of English. $4^{\text {th }} \mathrm{ed}$. Oxford: Oxford University Press, 1998.

5 H.W. Fowler's Modern English Usage $2^{\text {nd }}$ ed. Oxford University Press, 1977.

6 Council directive on the labelling of medicinal products for human use and on package leaflets. Official Journal of the European Communities 1992; L113(31 March): 8-12.(92/27/EEC). 